\title{
ADAPTIVE CHANGES IN PHYSIOLOGICAL TRAITS OF WHEAT GENOTYPES UNDER WATER DEFICIT CONDITIONS
}

\author{
AllAHVERDiYeV, T. I. ${ }^{1 *}-$ TALAI, J. M. $^{1}-$ HUSEYNOVA, I. M. ${ }^{2}$ \\ ${ }^{1}$ Research Institute of Crop Husbandry, Ministry of Agriculture of Azerbaijan Republic \\ Baku, Azerbaijan \\ ${ }^{2}$ Institute of Molecular Biology and Biotechnology, National Academy of Sciences of Azerbaijan \\ Republic, Baku, Azerbaijan \\ *Corresponding author \\ e-mail: tofig_1968@mail.ru; phone: +994-50-463-1989 \\ (Received 29 $9^{\text {th }}$ Sep 2017; accepted 22 ${ }^{\text {nd }}$ Dec 2017)
}

\begin{abstract}
Two year (2013/14 and 2014/15 growing seasons) field experiments were carried out to study the effect of soil water deficit on some physiological traits and grain yield of durum (Triticum durum Desf.) and bread wheat (Triticum aestivum L.) genotypes. Drought stress led to adaptive changes in physiological traits of wheat genotypes. Gas exchange parameters decreased significantly in response to water deficit. A reduction in relative water content was not strong. Genotypic differences in reducing the content of pigments, the relative stability of carotenoids to water stress were revealed. The leaf assimilation area of durum wheat genotypes exceeds that of bread wheat genotypes. Water stress caused acceleration of leaf senescence, inhibited an increase in the area of stem and spike. Adaptive changes in the distribution of assimilation area between leaves and stem were revealed. Unlike leaf assimilation area, stem assimilation area increased to stage of kernels watery ripe. Water stress caused an increase in proline content. Generally, grain yield was higher in genotypes of bread wheat than that of durum wheat, but a decrease in grain yield was over expressed in durum wheat. Grain yield less correlated with physiological traits. The decrease in the physiological parameters, as well as grain yield, was more expressed in 2013/14 growing season.
\end{abstract}

Keywords: Triticum durum Desf., Triticum aestivum L., drought, gas exchange, relative water content, chlorophyll, proline, grain yield

\section{Introduction}

Water deficit during growth and development of plants results in adaptive changes in the physiological and biochemical processes and morphological traits that allow the survival of the plants and formation of the yield. Wheat grain yield is significantly reduced in the arid and semi-arid regions of the world, where lack of water is also accompanied by high temperatures and high radiation levels. Wheat (Triticum spp.) is one of the first domesticated food crops and for 8000 years has been the basic staple food of major civilizations of Europe, West Asia, and North Africa (Monneveux et al., 2012). In parts of northern Africa and in the Caucasus region, annual consumption of wheat products per person is highest being at around $200 \mathrm{~kg}$ (Pingali, 1999). About 33\% of wheat fields in the world and about 55\% in the developing countries suffer from drought stress (Aghanejad et al., 2015). Wheat is one of the most important crops in Azerbaijan, where almost half of wheat growing areas are under rainfed conditions. Increasing wheat productivity is a national target in Azerbaijan to fill the gap between consumption and production.

Over the years, many physiological, morphological, and developmental traits have been suggested to be useful in improving drought tolerance (Quarrie et al., 1999; Wright 
and Rachaputi, 2004). Recent studies suggest that selection of physiological traits has the potential to improve wheat grain yield under drought (Reynolds et al., 2002; Condon et al., 2004).

The limitation of plant growth imposed by low water availability is mainly due to reductions of plant carbon balance, which is largely dependent on photosynthesis (Flexas et al., 2009). Photosynthetic responses to water stress have been the subject of studies and debates for decades, in particular, concerning which are the most limiting factors (stomatal or mesophyll limitations, photochemical and/or biochemical reactions) for photosynthesis under water stress (Flexas and Medrano, 2002; Lawlor and Cornic, 2002). The foliar photosynthetic rate of higher plants is known to decrease as the relative water content and leaf water potential decrease (Lawlor and Cornic, 2002). The decline of transpiration rate was mainly affected by stomatal conductance and the decline in photosynthesis rate was affected by non-stomatal factors (Changhai et al., 2010). Water deficit reduced leaf gas exchange and relative water content of durum wheat genotypes at anthesis and grain filling (Bogale et al., 2011). Morphophysiological traits can be used as indirect selection criteria for grain yield; however, their effectiveness depends on correlations with grain yield under drought and the degree to which each trait is genetically controlled (Nachit and Elouafi, 2004). Identifying wheat genotypes with suitable agronomical, morphological and physiological traits under water stress conditions is a main goal of wheat researchers.

The relationships between physiological traits and grain yield have not been identified clearly yet. We aimed to study adaptive changes in some physiological traits of wheat genotypes under drought stress, identify relations between physiological traits and grain yield.

\section{Materials and methods}

\section{Plant material and growth conditions}

Field experiments were conducted during the 2013/14 and 2014/15 growing seasons at the Research Institute of Crop Husbandry, located in the Apsheron peninsula, Baku. Plant materials consisted of 8 durum wheat (Triticum durum Desf.) genotypes Garagylchyg 2, Vugar, Shiraslan 23, Barakatli 95, Alinja 84, Tartar, Sharg, Gyrmyzy bugda and 14 bread wheat (Triticum aestivum L.) genotypes Nurlu 99, Gobustan, Akinchi 84, Giymatli 2\17, Gyrmyzy gul 1, Azamatli 95, Tale 38, Ruzi 84, Pirshahin 1, $12^{\text {nd }}$ FAWWON№97, $4^{\text {th }}$ FEFWSN№50, Gunashli, Dagdash, Saratovskaya 29. Sowing was performed in the third decade of October, at an average density of 400 seeds $/ \mathrm{m}^{2}$ with mechanical planter in $1 \times 10$ m plots, consisting of 7 rows placed $15 \mathrm{~cm}$ apart. Genotypes were grown in irrigated and rainfed plots with three replications. Irrigated plots were watered after the appearance of seedlings, at the stem elongation, anthesis and grain filling stages. Rainfed plots were not watered during ontogeny. Soil moisture content was determined at 0-20, 20-40 and 40-60 cm depths and was an average $60 \%$ in irrigated and $30 \%$ in rainfed plots at the grain formation stage.

\section{Measurements}

Gas exchange parameters (photosynthesis rate- $P_{n}$, stomatal conductance- $g_{s}$, intercellular $\mathrm{CO}_{2}$ concentration- $\mathrm{C}_{\mathrm{i}}$ and transpiration rate- $\mathrm{E}$ ) were measured using LICOR 6400XT Portable Photosynthesis System (LI-COR Biosciences, Lincoln, NE, 
USA). Gas exchange measurements were conducted at the booting (Feekes Stage 10), anthesis (Feekes 10.5.1) and kernels watery ripe (Feekes Stage 10.5.4) stages. Measurements were carried out between 10:00 and 12:00 a.m. Data logging started after $45 \mathrm{~s}$ of the insertion of leaves into chamber. The measurements of pigment-contents and relative water content were conducted at the kernels watery ripe stage. Leaf $\mathrm{Chl} a, b$ and Car $(x+c)$ contents were determined following the method of Lichtenthaler (1987), with little modifications. About $0.1 \mathrm{~g}$ of fresh leaves were ground in $96 \%$ ethanol for the extraction of chlorophyll and carotenoids. Absorbance of the supernatant was recorded at 664, 648, and $470 \mathrm{~nm}$, spectrophotometrically (Genesys 20, Thermo Scientific, USA). Pigment contents were calculated using the following formulas.

$$
\begin{aligned}
& \text { Chla }=\left(13.36 \cdot \mathrm{A}_{664}-5.19 \cdot \mathrm{A}_{648}\right) \cdot 25 / \mathrm{DW} ; \mathrm{Chlb}=\left(27.43 \cdot \mathrm{A}_{648}-8.12 \cdot \mathrm{A}_{664}\right) \cdot 25 / \mathrm{DW} \\
& \operatorname{Chl} \cdot(\mathrm{a}+\mathrm{b})=\left(5.24 \cdot \mathrm{A}_{664}+22.24 \cdot \mathrm{A}_{648}\right) \cdot 25 / \mathrm{DW} ; \\
& \operatorname{Car}(\mathrm{x}+\mathrm{c})=\left(4.785 \cdot \mathrm{A}_{470}+3.657 \cdot \mathrm{A}_{664}-12.76 \cdot \mathrm{A}_{648}\right) \cdot 25 / \mathrm{DW}
\end{aligned}
$$

Leaf area per stem (LAS), also projected area of stem multiplied by 3.14 according to Kvët and Marshall (1971), and spike multiplied by 2 according to Alvaro et al. (2008) were measured with an area meter (AAC-400, Hayashi Denkon Co, LTD, Japan). The flag leaf RWC was determined gravimetrically. RWC was calculated using the following formula: RWC $(\%)=(\mathrm{FW}-\mathrm{DW}) /(\mathrm{TW}-\mathrm{DW}) \times 100$, where FW-fresh mass, DWdry mass, TW-turgid mass. Proline content was determined following the method of Bates et al. (1973), with little modifications. About $0.5 \mathrm{~g}$ of leaves were homogenized in a pre-chilled pestle and mortar with $5 \mathrm{ml}$ of $3 \%$ sulphosalicylic acid. Then, the homogenate was centrifuged at $3500 \mathrm{~g}$ (HERMLEZ 400K, Germany) for $15 \mathrm{~min}$ at $4{ }^{\circ} \mathrm{C}$. The supernatant $(0.2 \mathrm{ml})$ was transferred to a plastic tube containing $3 \%$ ninhydrin $(0.4$ $\mathrm{ml}$ ), and $0.2 \mathrm{ml}$ of $96 \%$ acetic acid and $0.2 \mathrm{ml}$ of $3 \%$ sulphosalicylic acid were added. Tubes were incubated for $1 \mathrm{~h}$ at $96^{\circ} \mathrm{C}$ in a water-bath and $2 \mathrm{ml}$ of toluene was added to each tube, then stirred, and centrifuged at $3500 \mathrm{~g}$ for $15 \mathrm{~min}$ at $4^{\circ} \mathrm{C}$. The absorbance of the upper phase was measured at $520 \mathrm{~nm}$. The determination of proline was carried out with a calibration curve, constructed for a concentration range of 0.01-0.2 $\mathrm{mM}$ proline.

\section{Statistical analysis}

Correlations between traits were calculated using SPSS 16 software.

\section{Results}

Water deficit caused a decline in $\mathrm{P}_{\mathrm{n}}$ (Figs. 1 and 2), especially a big difference was detected between irrigated and exposed to drought plants at the anthesis stage. The $\mathrm{P}_{\mathrm{n}}$ of the genotypes Garagylchyg 2, Vugar, Barakatli 95, Nurlu 99, Gobustan, Akinchi 84, Azamatli 95, $12^{\text {nd }}$ FAWWON№97 and Saratovskaya 29 was susceptible to water deficit in both years, while the $\mathrm{P}_{\mathrm{n}}$ of the genotypes Sharg, Gyrmyzy bugda, Gyrmyzy gul 1, Dagdash was resistant. The $\mathrm{g}_{\mathrm{s}}$ of irrigated and rainfed plants was higher at the heading stage (Figs. 3 and 4), when the water status of leaves was relatively higher. 


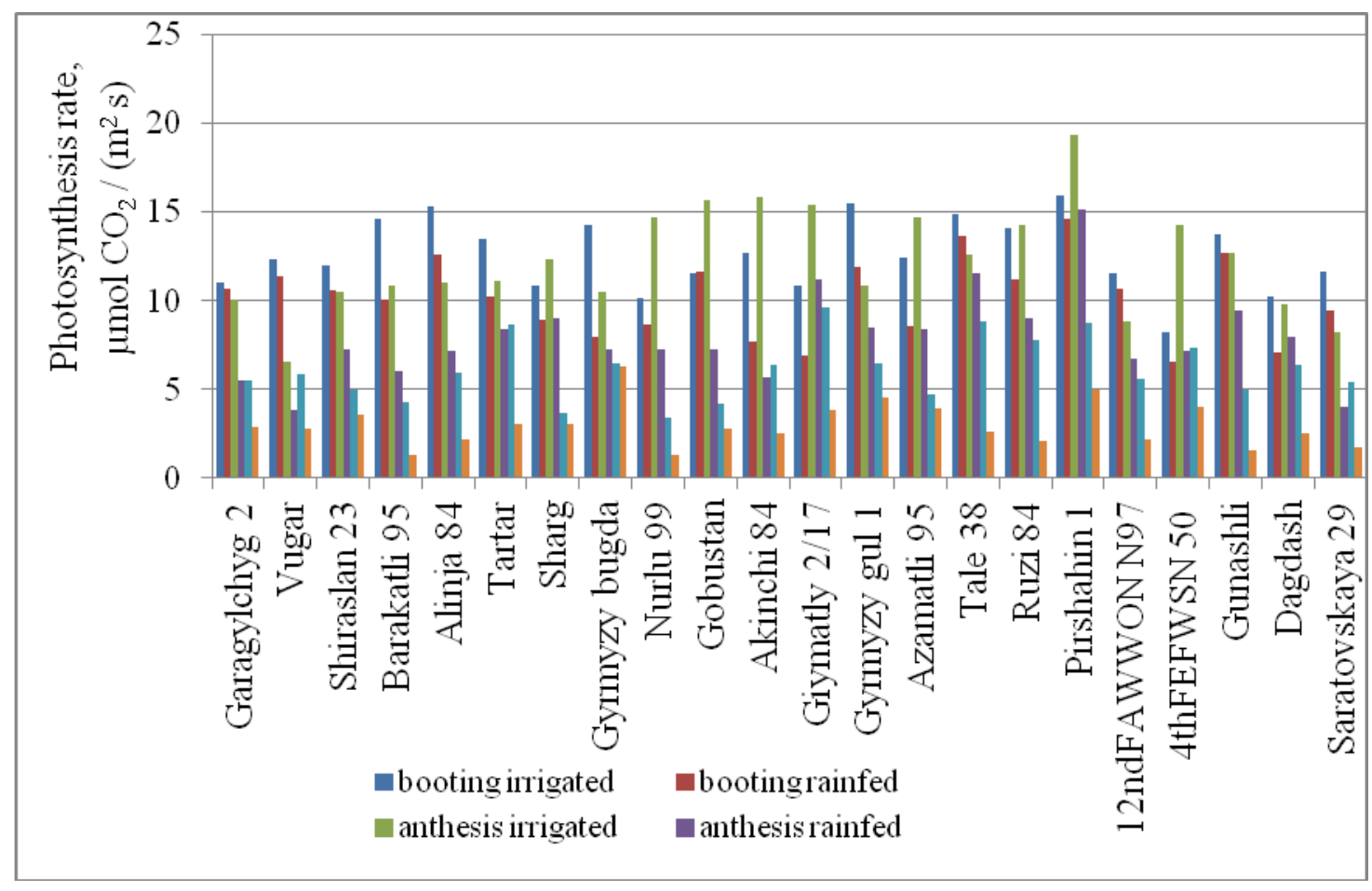

Figure 1. Effect of drought stress on photosynthesis rate- $P_{n}$ (2013/14). Each value represents mean of 7-9 replicates.

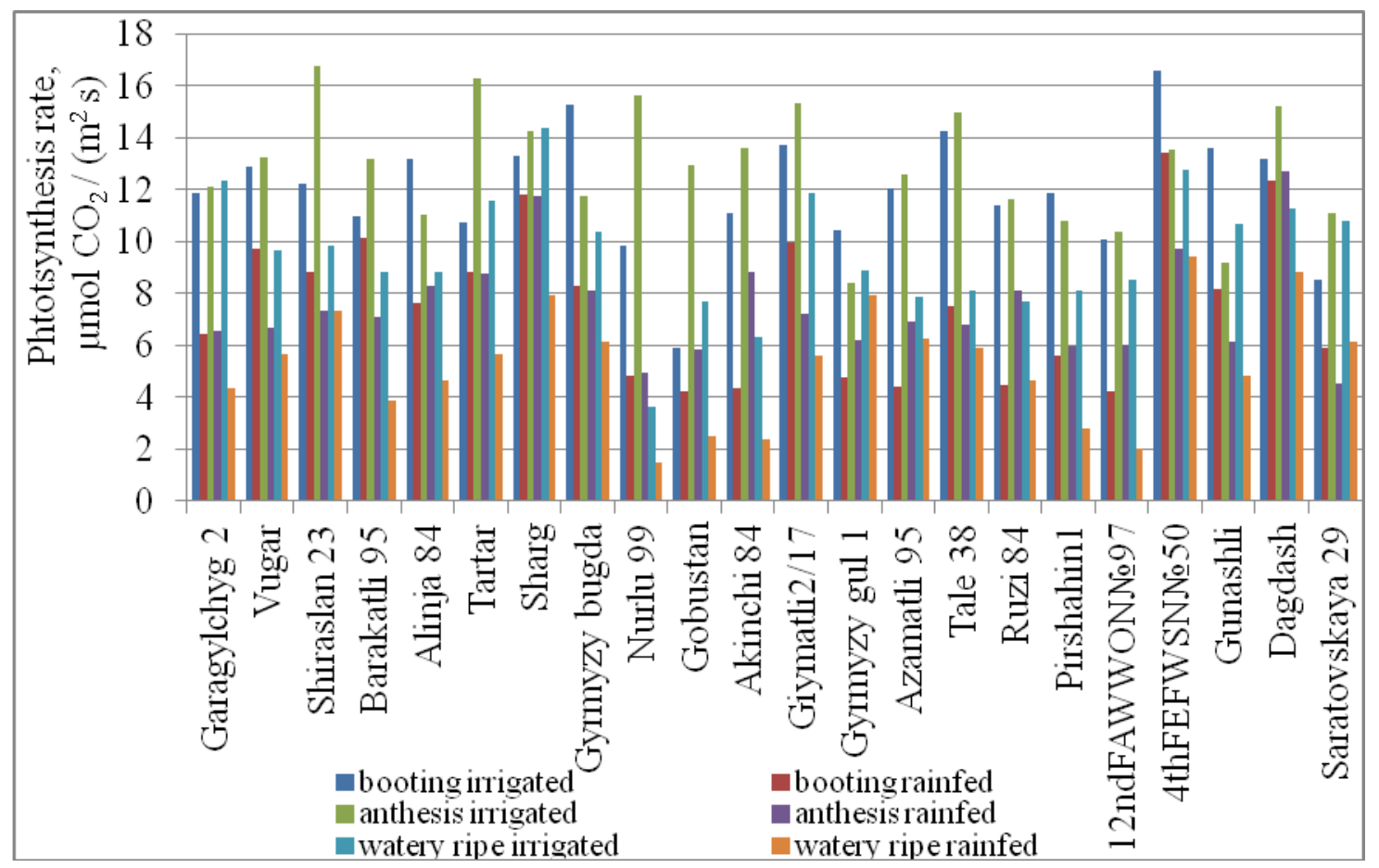

Figure 2. Effect of drought stress on photosynthesis rate- $P_{n}$ (2014/15). Each value represents mean of 7-9 replicates. 


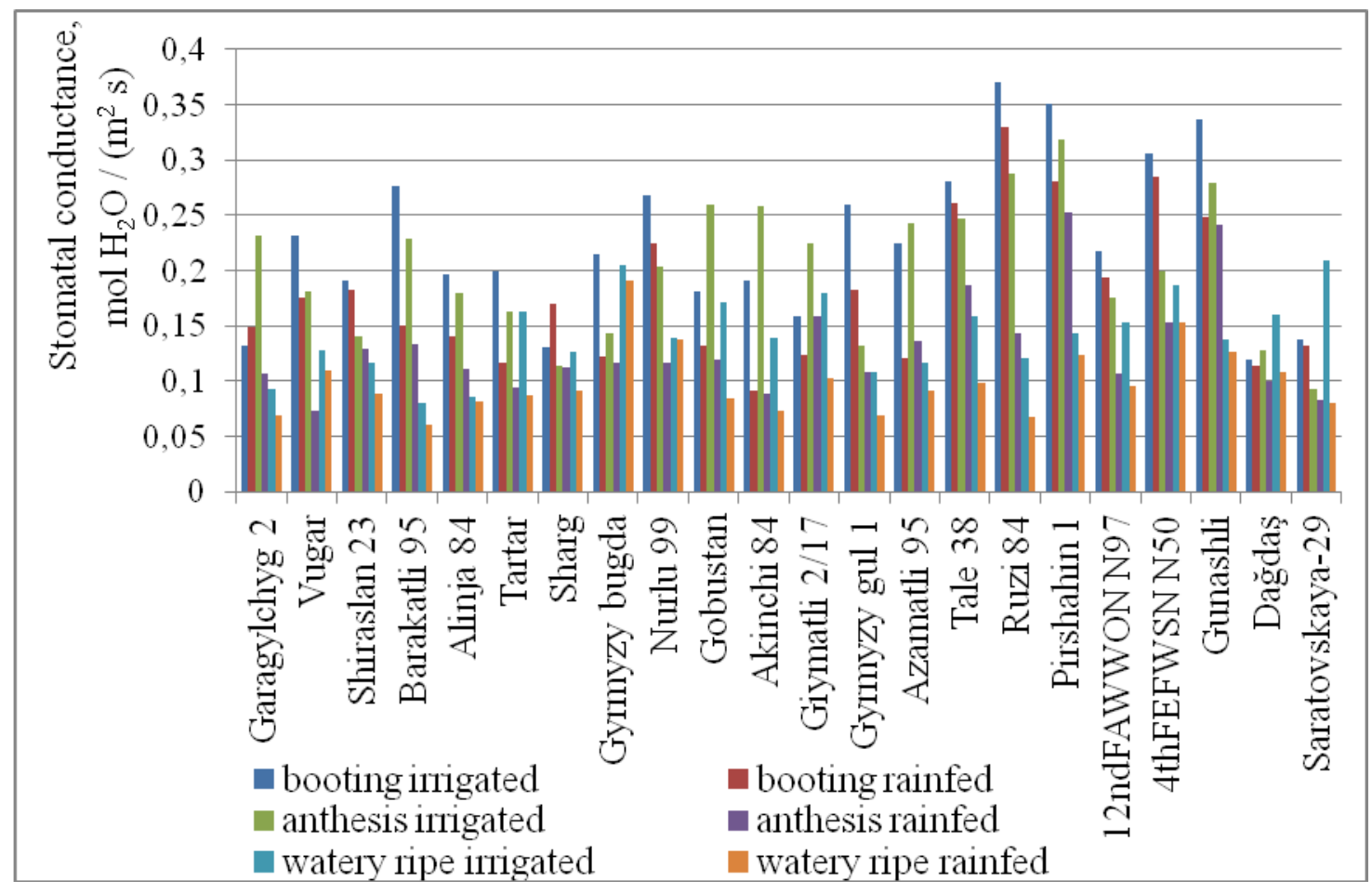

Figure 3. Effect of drought stress on stomatal conductance-g $g_{s}(2013 / 14)$. Each value represents mean of 7-9 replicates.

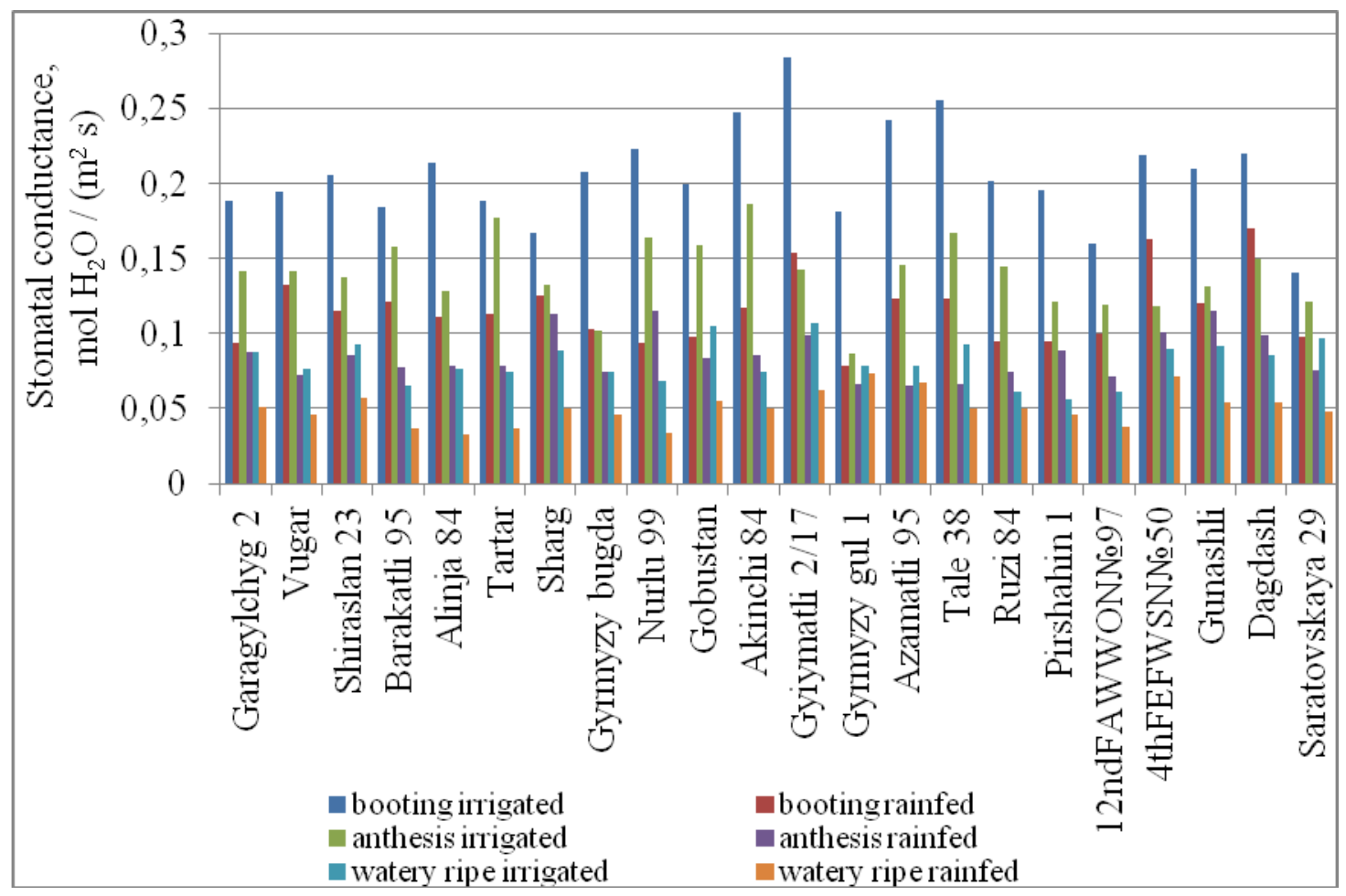

Figure 4. Effect of drought stress on stomatal conductance- $g_{s}$ (2014/15). Each value represents mean of 7-9 replicates. 
The $\mathrm{g}_{\mathrm{s}}$ of wheat genotypes declined sharply in response to water deficit. Drought stress caused a decline in $\mathrm{C}_{\mathrm{i}}$ at the booting stage in most genotypes. However, as the drought stress strengthened at following stages, the $\mathrm{C}_{\mathrm{i}}$ increased. The $\mathrm{E}$ was higher at the heading stage. Drought stress caused a strong reduction of $\mathrm{E}$, especially in the genotypes Alinja 84, Tartar, Gobustan, Akinchi 84, Giymatli 2/17, and Tale 38.

The rate of photosynthesis and stomatal conductance were higher in 2014/15 growing season than that in 2013/14.

Genotypic variations in RWC of flag leaves were revealed (Fig. 5). It was also found that the RWC of the leaves was higher in the 2014/15 growing season. A decrease in RWC of flag leaf was not strict and was about 4-10\% (2013/14) and 2-8\% (2014/15) in most wheat genotypes. A significant decline in RWC was found in the genotypes Barakatli-95 (10\%), Nurlu 99 (12\%), and Gunashli (26\%) in 2013/14, in the genotypes Gobustan (12\%), Tale 38 (10\%) and Azamatli 95 (26\%) in 2014/15. A slight decrease in RWC was assumed to be associated with a profound reduction in $\mathrm{g}_{\mathrm{s}}$ and accumulation of osmotically active compounds.

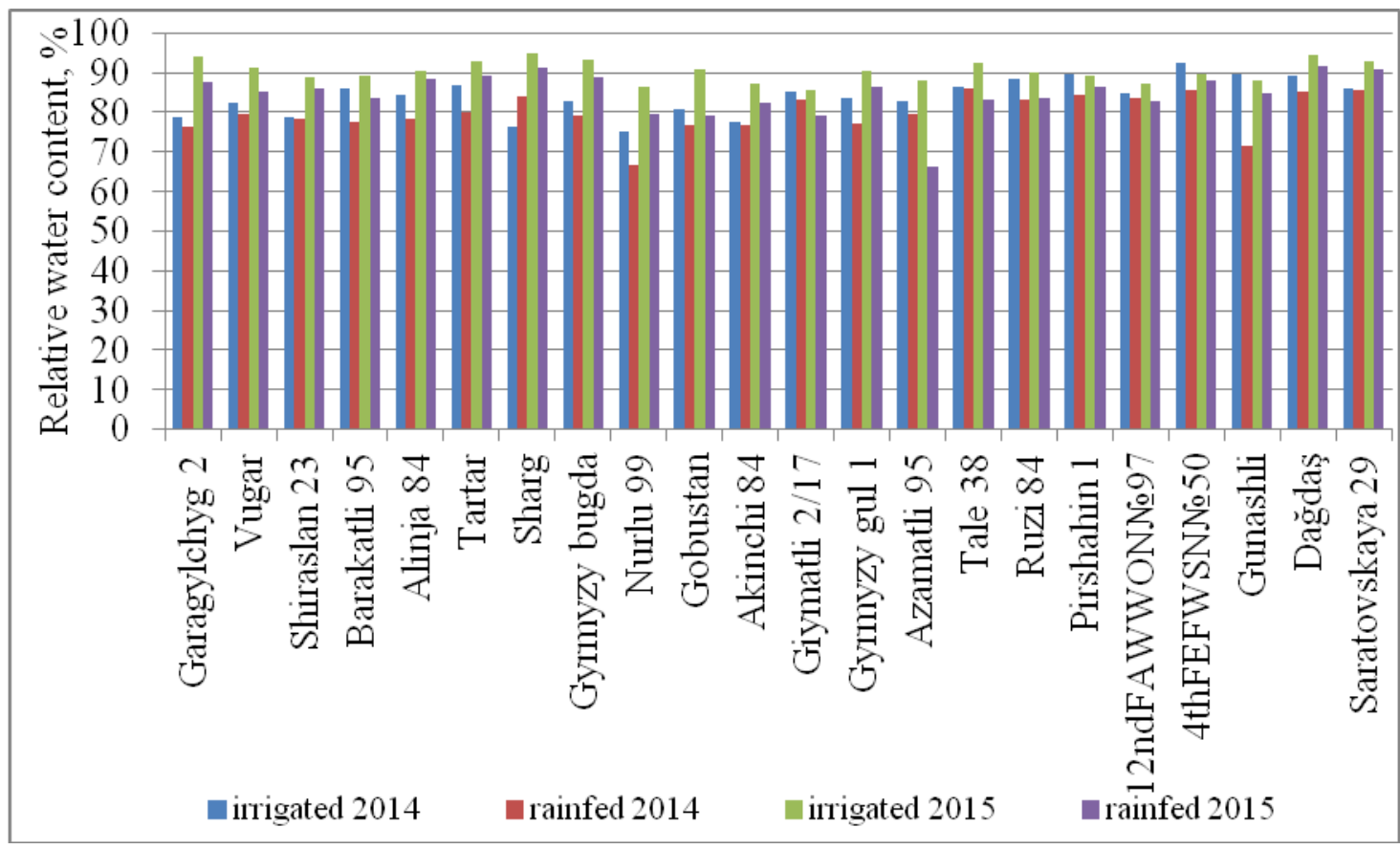

Figure 5. Effect of drought stress on flag leaf relative water content. Each value represents mean of 3 replicates.

The contents of $\mathrm{Chl}(\mathrm{a}+\mathrm{b})$ and $\mathrm{Car}(\mathrm{x}+\mathrm{c})$ was higher in the 2014/15 growing season than in the 2013/14 growing season (Tables 1 and 2). A higher content of pigments was found under irrigation in the genotypes Garagylchyg 2, Tartar, Barakatli 95, Gobustan, Giymatli 2/17, Gyrmyzy gul 1, Tale 38, $4^{\text {th }}$ FEFWSN№50, Saratovskaya 29, whereas low levels of pigments were found in the genotypes Shiraslan 23, Nurlu 99, Azamatli 95. Water shortage greatly affected the pigment content of the genotypes Garagylchyg 2, Tartar, Gobustan, Akinchi 84, Gunashli, whereas a slight decrease was detected in genotypes Vugar, Gyrmyzy gul 1, Tale 38, Azamatli 95 and Saratovskaya 29. An increase in the $\mathrm{Chl} \mathrm{a/b}$ ratio in half of all genotypes was identified. Reducing the 
$\operatorname{Chl}(\mathrm{a}+\mathrm{b}) / \operatorname{Car}(\mathrm{x}+\mathrm{c})$ ratio was identified in the majority of genotypes, indicating a relative resistance of carotenoids to water shortage.

Table 1. Effect of drought stress on flag leaf photosynthetic pigments content (2013/14).

Each value represents mean of 3 replicates.

\begin{tabular}{|c|c|c|c|c|c|c|c|}
\hline \multirow{2}{*}{ Genotypes } & \multirow{2}{*}{$\begin{array}{c}\text { Growth } \\
\text { condition }\end{array}$} & Chl a & Chl b & $\begin{array}{c}\text { Chl } \\
(\mathbf{a}+\mathbf{b})\end{array}$ & Car $(x+c)$ & \multirow{2}{*}{ Chl a/b } & \multirow{2}{*}{$\begin{array}{c}\text { Chl }(\mathbf{a}+\mathbf{b}) / \mathrm{Kar} \\
(\mathbf{x}+\mathbf{c})\end{array}$} \\
\hline & & \multicolumn{4}{|c|}{$\mathrm{mg} \mathrm{g}^{-1}$ dry mass } & & \\
\hline \multicolumn{8}{|c|}{ Triticum durum Desf. } \\
\hline \multirow{2}{*}{ Garagylchyg 2} & Irrigated & 6.34 & 2.56 & 8.9 & 1.48 & 2.47 & 6.01 \\
\hline & Rainfed & 3.08 & 1.75 & 4.83 & 0.63 & 1.77 & 7.66 \\
\hline \multirow{2}{*}{ Vugar } & Irrigated & 6.29 & 2.70 & 8.98 & 1.33 & 2.33 & 6.75 \\
\hline & Rainfed & 6.04 & 2.70 & 8.74 & 1.40 & 2.23 & 6.24 \\
\hline \multirow{2}{*}{ Shiraslan 23} & Irrigated & 5.54 & 2.82 & 8.36 & 1.02 & 1.96 & 8.23 \\
\hline & Rainfed & 4.16 & 2.15 & 6.31 & 1.01 & 1.93 & 6.27 \\
\hline \multirow{2}{*}{ Barakatli 95} & Irrigated & 6.85 & 2.91 & 9.75 & 1.53 & 2.36 & 6.37 \\
\hline & Rainfed & 5.36 & 2.40 & 7.76 & 1.15 & 2.23 & 6.75 \\
\hline \multirow{2}{*}{ Alinja 84} & Irrigated & 5.68 & 2.67 & 8.36 & 1.24 & 2.13 & 6.73 \\
\hline & Rainfed & 4.72 & 2.35 & 7.06 & 0.98 & 2.01 & 7.16 \\
\hline \multirow{2}{*}{ Tartar } & Irrigated & 10.04 & 3.99 & 14.02 & 2.08 & 2.52 & 6.74 \\
\hline & Rainfed & 4.57 & 1.83 & 6.40 & 1.09 & 2.50 & 5.87 \\
\hline \multirow{2}{*}{ Sharg } & Irrigated & 5.16 & 1.93 & 7.08 & 1.46 & 2.67 & 4.84 \\
\hline & Rainfed & 3.97 & 1.47 & 5.44 & 1.36 & 2.69 & 4.01 \\
\hline \multirow{2}{*}{ Gyrmyzy bugda } & Irrigated & 5.84 & 2.07 & 7.91 & 1.47 & 2.81 & 5.38 \\
\hline & Rainfed & 5.04 & 1.79 & 6.83 & 1.49 & 2.81 & 4.57 \\
\hline \multicolumn{8}{|c|}{ Triticum aestivum $\mathrm{L}}$. \\
\hline \multirow{2}{*}{ Nurlu 99} & Irrigated & 6.06 & 2.42 & 8.48 & 1.45 & 2.51 & 5.83 \\
\hline & Rainfed & 3.12 & 1.21 & 4.33 & 1.03 & 2.59 & 4.22 \\
\hline \multirow{2}{*}{ Gobustan } & Irrigated & 7.82 & 3.04 & 10.85 & 1.65 & 2.57 & 6.57 \\
\hline & Rainfed & 3.23 & 1.35 & 4.58 & 0.82 & 2.40 & 5.56 \\
\hline \multirow{2}{*}{ Akinchi 84} & Irrigated & 7.98 & 3.12 & 11.10 & 1.87 & 2.55 & 5.92 \\
\hline & Rainfed & 4.77 & 1.90 & 6.67 & 1.43 & 2.51 & 4.67 \\
\hline \multirow{2}{*}{ Giymatli 2/17 } & Irrigated & 6.63 & 2.87 & 9.50 & 1.37 & 2.31 & 6.93 \\
\hline & Rainfed & 4.97 & 1.78 & 6.75 & 1.18 & 2.78 & 5.74 \\
\hline \multirow{2}{*}{ Gyrmyzy gul1 } & Irrigated & 8.02 & 3.10 & 11.12 & 1.70 & 2.59 & 6.54 \\
\hline & Rainfed & 5.99 & 2.32 & 8.31 & 1.33 & 2.59 & 6.24 \\
\hline \multirow{2}{*}{ Azamatli 95} & Irrigated & 5.88 & 2.37 & 8.25 & 1.29 & 2.48 & 6.39 \\
\hline & Rainfed & 5.17 & 2.17 & 7.34 & 1.34 & 2.39 & 5.48 \\
\hline \multirow{2}{*}{ Tale 38} & Irrigated & 7.52 & 3.01 & 10.53 & 1.58 & 2.50 & 6.65 \\
\hline & Rainfed & 5.86 & 2.26 & 8.12 & 1.44 & 2.59 & 5.62 \\
\hline \multirow{2}{*}{ Ruzi 84} & Irrigated & 5.92 & 2.23 & 8.15 & 1.60 & 2.66 & 5.09 \\
\hline & Rainfed & 4.23 & 1.72 & 5.95 & 1.25 & 2.47 & 4.75 \\
\hline \multirow{2}{*}{ Pirshahin 1} & Irrigated & 5.31 & 2.56 & 7.87 & 1.21 & 2.08 & 6.50 \\
\hline & Rainfed & 3.58 & 1.49 & 5.07 & 1.31 & 2.41 & 4.48 \\
\hline
\end{tabular}




\begin{tabular}{|c|c|c|c|c|c|c|c|}
\hline \multirow{2}{*}{$12^{\text {nd }}$ FAWWON№97 } & Irrigated & 6.48 & 2.86 & 9.34 & 1.40 & 2.27 & 6.68 \\
\cline { 2 - 8 } & Rainfed & 5.25 & 2.24 & 7.49 & 1.41 & 2.34 & 5.30 \\
\hline \multirow{2}{*}{$4^{\text {th }}$ FEFWSNNo50 } & Irrigated & 6.97 & 2.94 & 9.90 & 1.61 & 2.37 & 6.16 \\
\cline { 2 - 8 } & Rainfed & 5.42 & 2.18 & 7.60 & 1.41 & 2.48 & 5.40 \\
\hline \multirow{2}{*}{ Günashli } & Irrigated & 6.46 & 2.44 & 8.90 & 1.59 & 2.64 & 5.60 \\
\cline { 2 - 8 } & Rainfed & 3.13 & 1.16 & 4.28 & 1.25 & 2.70 & 3.42 \\
\hline \multirow{2}{*}{ Dagdash } & Irrigated & 7.34 & 2.77 & 10.11 & 1.73 & 2.65 & 5.83 \\
\cline { 2 - 8 } & Rainfed & 6.35 & 2.38 & 8.73 & 1.87 & 2.66 & 4.66 \\
\hline \multirow{2}{*}{ Saratovskaya 29 } & Irrigated & 7.20 & 2.73 & 9.93 & 1.71 & 2.64 & 5.82 \\
\cline { 2 - 8 } & Rainfed & 6.79 & 2.59 & 9.38 & 1.65 & 2.62 & 5.67 \\
\hline
\end{tabular}

Table 2. Effect of drought stress on flag leaf photosynthetic pigments content (2014/15).

Each value represents mean of 3 replicates.

\begin{tabular}{|c|c|c|c|c|c|c|c|}
\hline \multirow[t]{2}{*}{ Genotypes } & \multirow{2}{*}{$\begin{array}{c}\text { Growth } \\
\text { condition }\end{array}$} & Chl a & Chl b & $\begin{array}{c}\text { Chl } \\
(\mathbf{a}+\mathbf{b})\end{array}$ & $\operatorname{Car}(x+c)$ & \multirow[t]{2}{*}{ Chl $\mathbf{a} / \mathbf{b}$} & \multirow{2}{*}{$\begin{array}{c}\text { Chl } \\
(\mathbf{a}+\mathbf{b}) / \mathrm{Kar} \\
(\mathbf{x}+\mathbf{c})\end{array}$} \\
\hline & & \multicolumn{4}{|c|}{$\mathrm{mg} \mathrm{g}^{-1}$ dry mass } & & \\
\hline \multicolumn{8}{|c|}{ Triticum durum Desf. } \\
\hline \multirow{2}{*}{ Garagylchyg 2} & Irrigated & 7.51 & 2.65 & 10.16 & 2.29 & 2.84 & 4.43 \\
\hline & Rainfed & 4.89 & 1.88 & 6.77 & 1.73 & 2.60 & 3.92 \\
\hline \multirow{2}{*}{ Vugar } & Irrigated & 6.82 & 2.38 & 9.20 & 2.16 & 2.87 & 4.26 \\
\hline & Rainfed & 5.87 & 2.04 & 7.91 & 1.71 & 2.88 & 4.63 \\
\hline \multirow{2}{*}{ Shiraslan 23} & Irrigated & 5.23 & 1.92 & 7.15 & 1.47 & 2.73 & 4.86 \\
\hline & Rainfed & 5.15 & 1.77 & 6.92 & 1.65 & 2.91 & 4.19 \\
\hline \multirow{2}{*}{ Barakatli 95} & Irrigated & 7.16 & 2.65 & 9.81 & 2.02 & 2.70 & 4.85 \\
\hline & Rainfed & 6.60 & 2.52 & 9.12 & 1.87 & 2.62 & 4.87 \\
\hline \multirow{2}{*}{ Alinja 84} & Irrigated & 6.59 & 2.47 & 9.06 & 1,87 & 2,66 & 4,85 \\
\hline & Rainfed & 5.41 & 1.89 & 7.29 & 1.65 & 2.86 & 4.43 \\
\hline \multirow{2}{*}{ Tartar } & Irrigated & 7.48 & 2.93 & 10.41 & 2.16 & 2.55 & 4.83 \\
\hline & Rainfed & 5.98 & 2.38 & 8.36 & 1.78 & 2.52 & 4.69 \\
\hline \multirow{2}{*}{ Sharg } & Irrigated & 6.52 & 2.34 & 8.86 & 1.90 & 2.78 & 4.66 \\
\hline & Rainfed & 5.09 & 1.66 & 6.75 & 1.63 & 3.07 & 4.15 \\
\hline \multirow{2}{*}{ Gyrmyzy bugda } & Irrigated & 7.63 & 2.54 & 10.17 & 2.14 & 3.01 & 4.76 \\
\hline & Rainfed & 6.06 & 2.05 & 8.11 & 1.77 & 2.96 & 4.57 \\
\hline \multicolumn{8}{|c|}{ Triticum aestivum $\mathrm{L}$. } \\
\hline \multirow{2}{*}{ Nurlu 99} & Irrigated & 4.32 & 1.62 & 5.94 & 1.27 & 2.67 & 4.69 \\
\hline & Rainfed & 4.14 & 1.53 & 5.67 & 1.16 & 2.70 & 4.91 \\
\hline \multirow{2}{*}{ Gobustan } & Irrigated & 7.82 & 2.80 & 10.62 & 2.15 & 2.79 & 4.94 \\
\hline & Rainfed & 4.85 & 1.61 & 6.45 & 1.41 & 3.01 & 4.58 \\
\hline \multirow{2}{*}{ Akinchi 84} & Irrigated & 6.51 & 2.43 & 8.95 & 1.95 & 2.68 & 4.60 \\
\hline & Rainfed & 4.78 & 1.81 & 6.59 & 0.74 & 2.65 & 8.92 \\
\hline \multirow{2}{*}{ Giymatli 2/17 } & Irrigated & 7.78 & 2.72 & 10.50 & 2.24 & 2.86 & 4.70 \\
\hline & Rainfed & 6.18 & 2.19 & 8.37 & 1.72 & 2.82 & 4.87 \\
\hline
\end{tabular}




\begin{tabular}{|c|c|c|c|c|c|c|c|}
\hline \multirow{2}{*}{ Gyrmyzy gul1 } & Irrigated & 7.96 & 2.96 & 10.92 & 2.26 & 2.69 & 4.84 \\
\cline { 2 - 8 } & Rainfed & 7.71 & 2.84 & 10.55 & 2.25 & 2.72 & 4.67 \\
\hline \multirow{2}{*}{ Azamatli 95 } & Irrigated & 4.87 & 2.09 & 6.95 & 1.34 & 2.33 & 5.20 \\
\cline { 2 - 8 } & Rainfed & 5.23 & 1.95 & 7.18 & 1.46 & 2.67 & 4.92 \\
\hline \multirow{2}{*}{ Tale 38 } & Irrigated & 7.22 & 2.57 & 9.79 & 2.07 & 2.81 & 4.73 \\
\cline { 2 - 8 } & Rainfed & 6.56 & 2.48 & 9.03 & 1.90 & 2.65 & 4.75 \\
\hline \multirow{2}{*}{ Ruzi 84 } & Irrigated & 6.76 & 2.36 & 9.12 & 1.93 & 2.86 & 4.73 \\
\cline { 2 - 8 } & Rainfed & 5.58 & 1.95 & 7.54 & 1.58 & 2.86 & 4.77 \\
\hline \multirow{2}{*}{ Pirshahin 1 } & Irrigated & 7.01 & 2.54 & 9.55 & 2.01 & 2.76 & 4.76 \\
\cline { 2 - 8 } & Rainfed & 6.31 & 2.25 & 8.56 & 1.88 & 2.80 & 4.55 \\
\hline \multirow{2}{*}{$12^{\text {nd }}$ FAWWON№97 } & Irrigated & 6.97 & 2.51 & 9.48 & 2.04 & 2.77 & 4.64 \\
\cline { 2 - 8 } & Rainfed & 6.12 & 2.43 & 8.55 & 1.72 & 2.52 & 4.97 \\
\hline \multirow{2}{*}{$4{ }^{\text {th }}$ FEFWSN№50 } & Irrigated & 7.68 & 2.78 & 10.46 & 2.23 & 2.76 & 4.70 \\
\cline { 2 - 8 } & Rainfed & 6.17 & 2.29 & 8.45 & 1.88 & 2.70 & 4.50 \\
\hline \multirow{2}{*}{ Günashli } & Irrigated & 7.26 & 2.72 & 9.98 & 1.92 & 2.67 & 5.20 \\
\cline { 2 - 7 } & Rainfed & 5.08 & 1.95 & 7.03 & 1.44 & 2.61 & 4.87 \\
\hline \multirow{2}{*}{ Dagdash } & Irrigated & 6.39 & 2.14 & 8.52 & 1.99 & 2.99 & 4.28 \\
\cline { 2 - 7 } & Rainfed & 5.66 & 2.00 & 7.66 & 1.93 & 2.83 & 3.97 \\
\hline \multirow{2}{*}{ Saratovskaya 29 } & Irrigated & 7.80 & 2.97 & 10.78 & 2.06 & 2.62 & 5.24 \\
\cline { 2 - 7 } & Rainfed & 7.00 & 2.53 & 9.53 & 2.05 & 2.77 & 4.66 \\
\hline
\end{tabular}

Durum wheat genotypes formed a greater leaf area per stem compared to bread wheat genotypes until the heading stage (Figs. 6 and 7). The largest area of leaves per stem was formed in genotypes of durum wheat Vugar, Alinja 84, Tartar and in bread wheat Giymatli 2/17. The genotypes Giymatli 2/17, Gyrmyzy gul 1 and Tale 38 are also characterized by higher leaf area index (data are not shown). Water shortage caused a reduction in assimilation area of leaves. A decrease in leaf area at following growth stages occurred both in irrigated and rainfed plants, but water deficit accelerated leaf senescence. An increase in stem assimilation area of stem was detected in some genotypes under water deficit, which can be explained as a compensation of leaf area reduction (Fig. 8). In most genotypes an increase in stem assimilation area continued until the kernels watery ripe stage in the favorable 2014/15 growing season (Fig. 9). A high assimilation area of stem was revealed in the taller genotypes Sharg, Gyrmyzy bugda, and in the genotypes Akinchi 84 and Giymatli 2/17 whereas a low assimilation area of stem was revealed in genotypes Gyrmyzy gul 1, $12^{\text {nd }}$ FAWWON№97 and Gunashli. Water deficit slowed an increase in stem assimilation area. A large decrease in the assimilation area of stem was found to kernels watery ripe stage in the genotypes Tartar, Gyrmyzy bugda, Akinchi 84, Ruzi-84, $4^{\text {th }}$ FEFWSN№50 and Dagdash. The assimilation area of spike was relatively greater in most genotypes of durum wheat than that of bread wheat (data are not shown). Under the condition of water scarcity a great delay in the formation of the assimilation area of spike was observed in the genotypes Gyrmyzy gul 1, Azamatli 95, Tale 38, $12^{\text {nd }}$ FAWWON№97 and Dagdash.

Proline content increased under drought conditions, especially in the genotypes Tartar, Giymatli 2/17, Azamatli 95, Tale 38 (Fig. 10). The substantial content of proline in irrigated plants is probably associated with the senescense of leaves. 


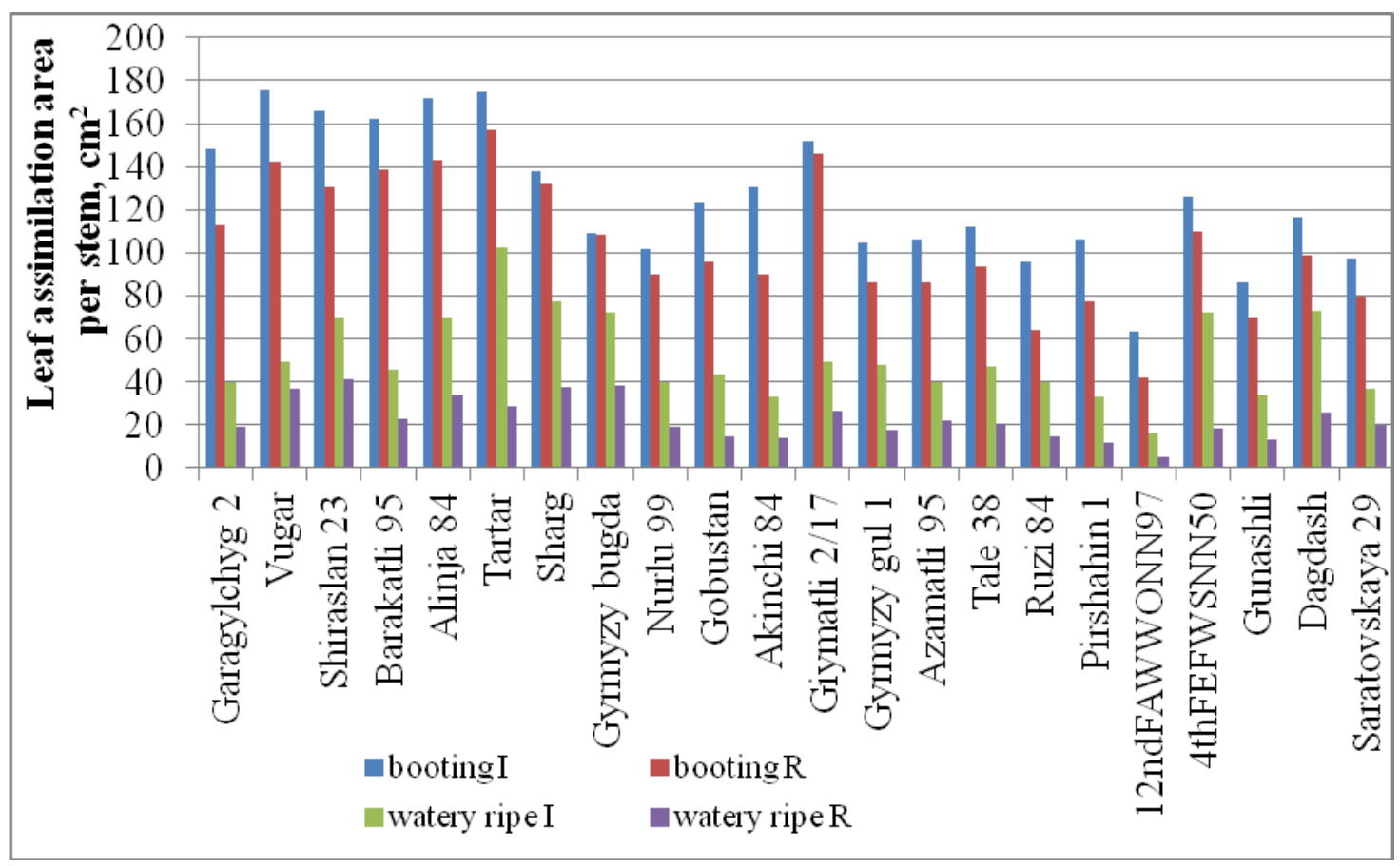

Figure 6. Effect of drought stress on leaf area per stem (2013/14). Each value represent mean of 7 replicates. I-irrigated, $R$-rainfed.

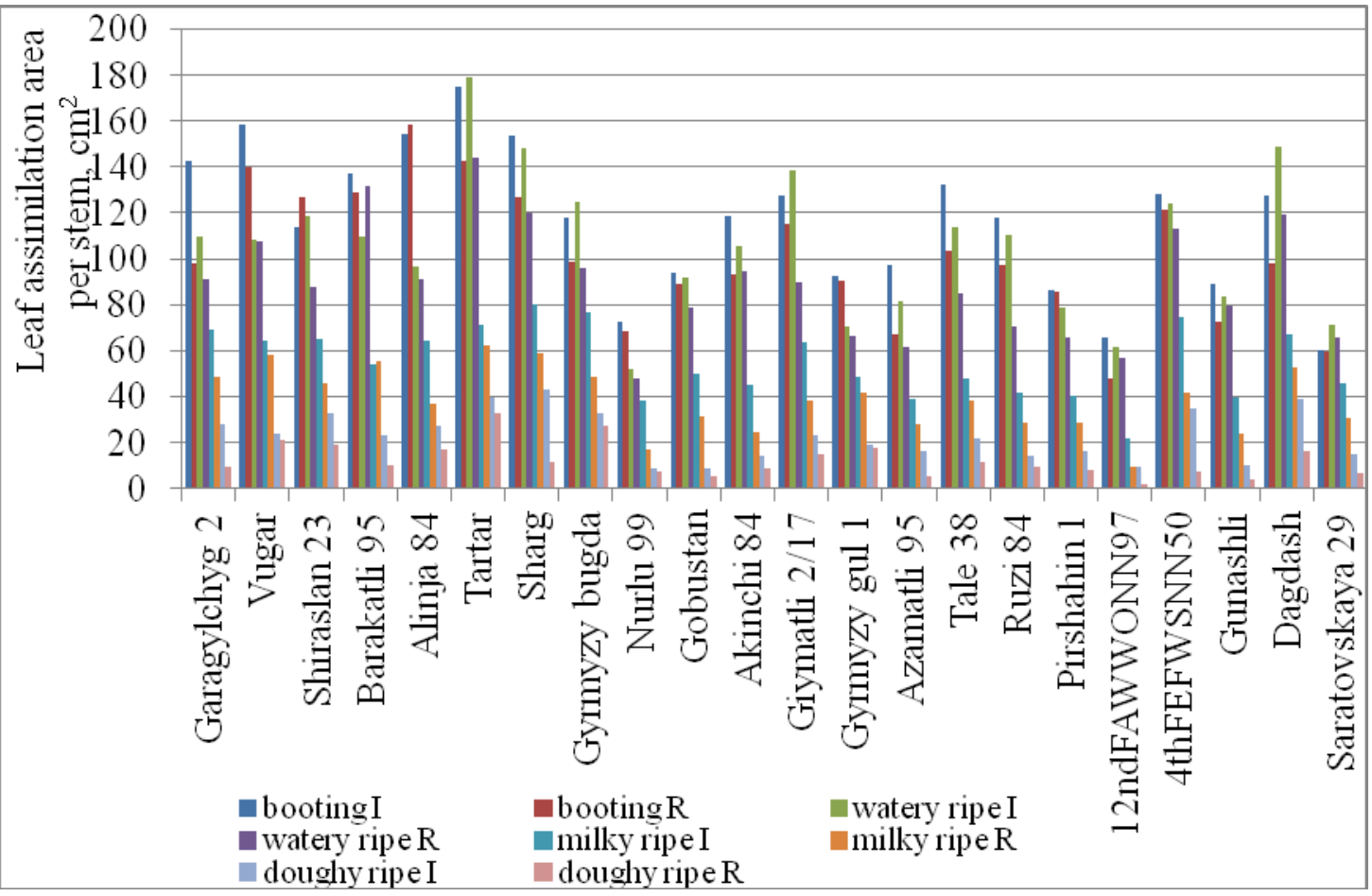

Figure 7. Effect of drought stress on leaf area per stem (2014/15). Each value represent mean of 7 replicates. I-irrigated, $R$-rainfed. 


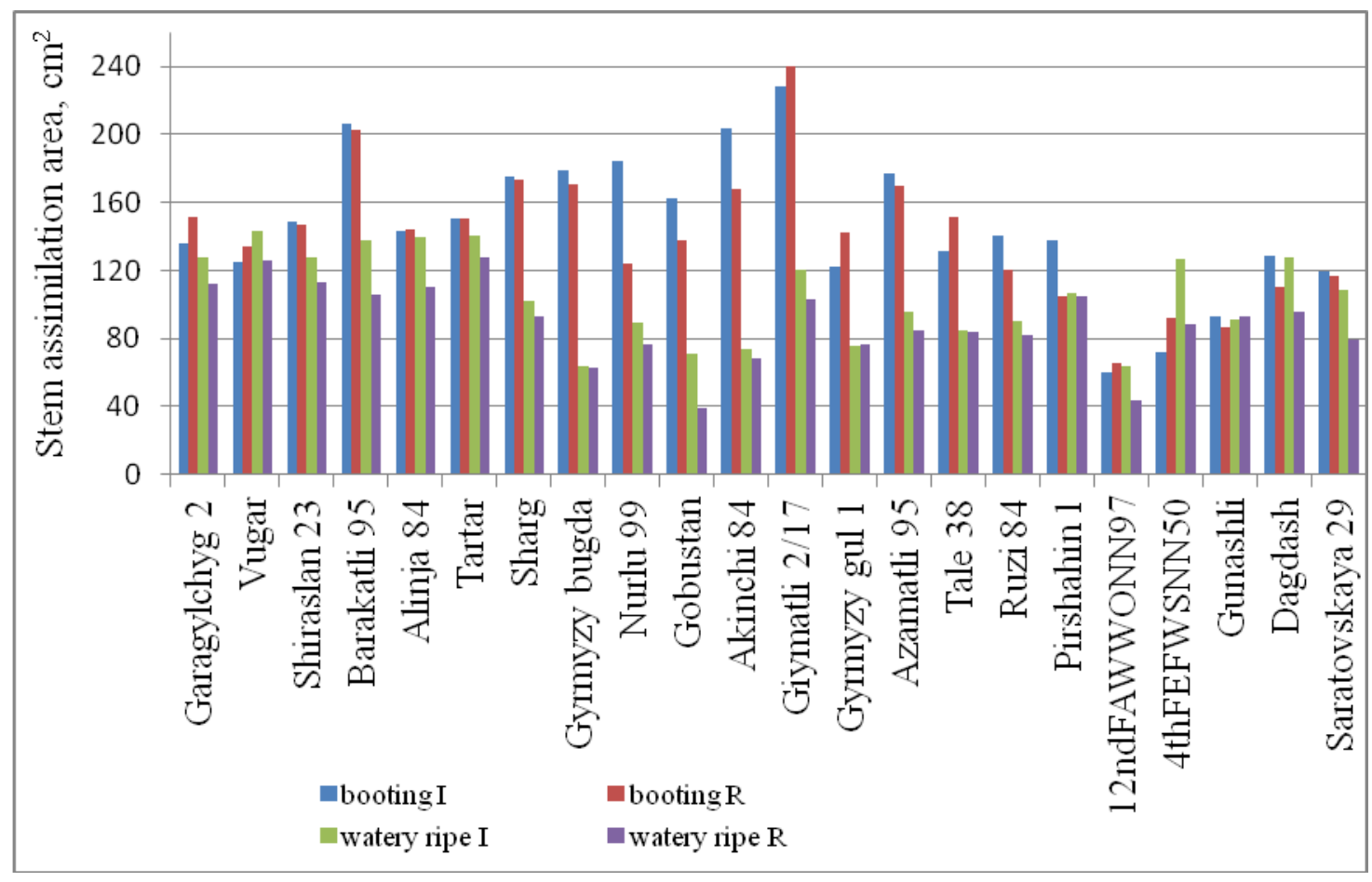

Figure 8. Effect of drought stress on stem assimilation area (2013/14). Each value represent mean of 7 replicates.

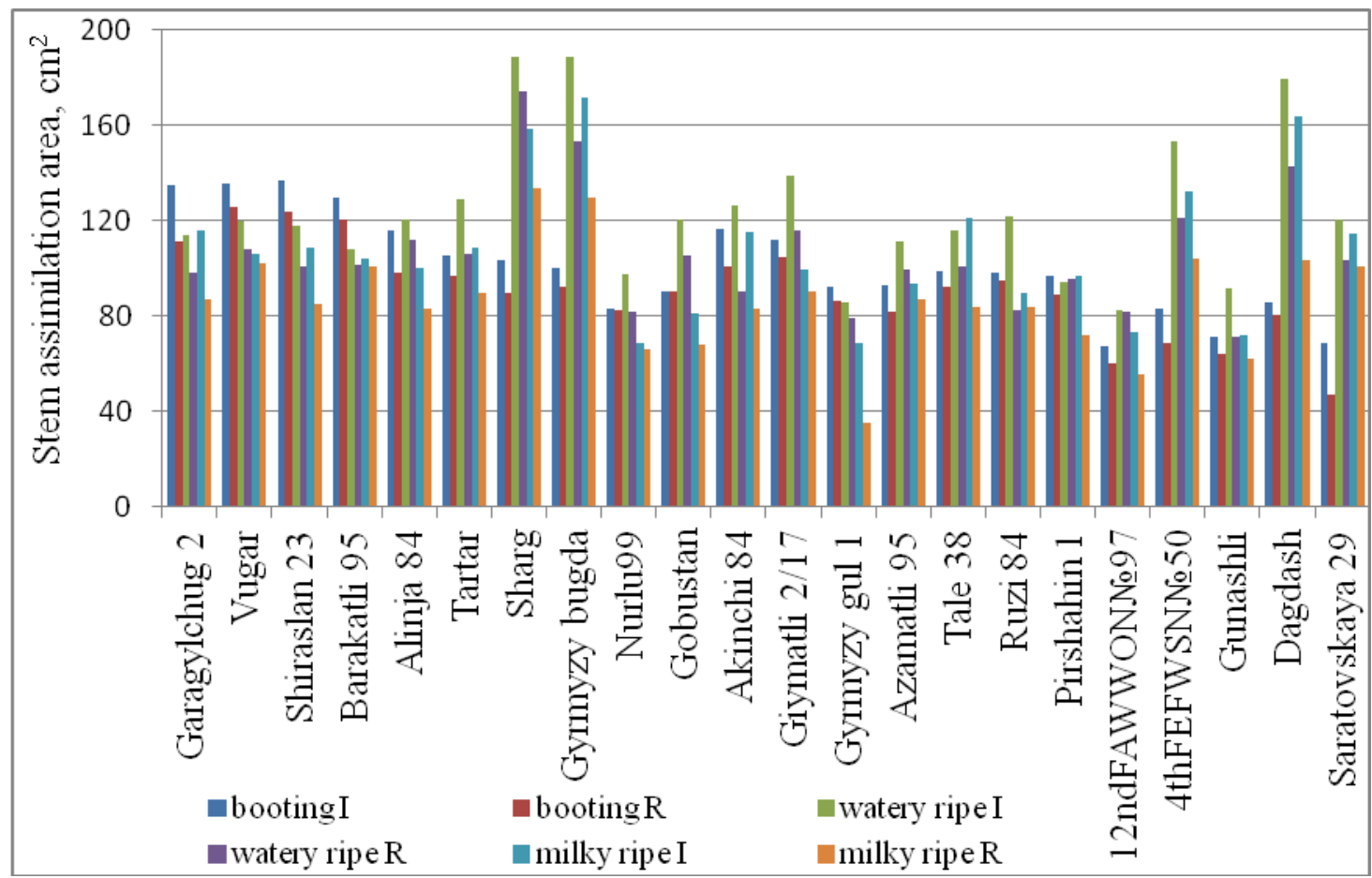

Figure 9. Effect of drought stress on stem assimilation area (2014/15). Each value represent mean of 7 replicates. 


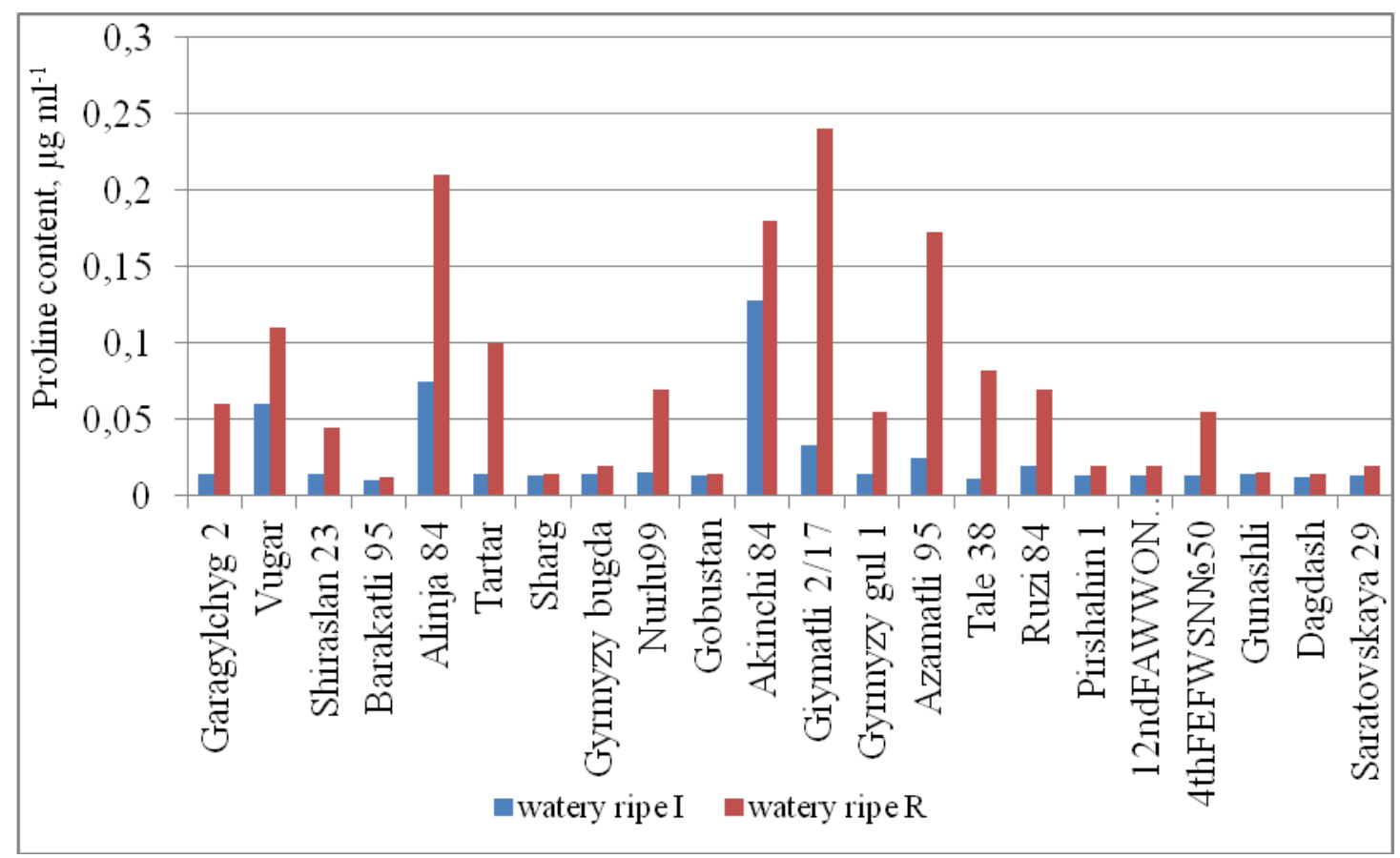

Figure 10. Effect of drought stress on proline content (2014/15). Each value represent mean of 3 replicates.

The grain yield of the majority of genotypes was higher in the 2013/14 growing season than that in the 2014-2015 growing season under irrigation (Fig. 11). However the grain yield of most genotypes was relatively higher in the 2014/15 growing season under rainfed condition. A relatively strong reduction in grain yield of genotypes occurred in the 2013/14 growing season. An average grain yield of durum and bread wheat genotypes was $588.6 \mathrm{~g} / \mathrm{m}^{2}$ and $670 \mathrm{~g} / \mathrm{m}^{2}$ under irrigation, $357.4 \mathrm{~g} / \mathrm{m}^{2}$ and $451.5 \mathrm{~g} / \mathrm{m}^{2}$ under rainfed condition in the $2013 / 14$ growing season. An average grain yield of durum and bread wheat genotypes was 539.3 and $558.4 \mathrm{~g} / \mathrm{m}^{2}$ under irrigation, and 382.8 and $443.2 \mathrm{~g} / \mathrm{m}^{2}$ under rainfed condition in the $2014 / 15$ growing season. Reduction of grain yield was $39 \%$ for durum wheat, $33 \%$ for bread wheat in the 2013/14 growing season and 29\% for durum wheat, $21 \%$ for bread wheat in the 2014/15 growing season, respectively. A potential productivity of genotypes Garagylchyg 2, Barakatli 95, Tartar, Giymatli 2/17, Gyrmyzy gul 1, Tale 38, Pirshahin 1, $4^{\text {th }}$ FEFWSN№50 were higher under irrigation in the studied years. Genotypes Vugar, Sharg, Gyrmyzy bugda, Nurlu 99, Gobustan, Ruzi 84, $12^{\text {nd }}$ FAWWONNNo97, Gunashli, Saratovskaya 29 formed stable grain yield under irrigated and rainfed conditions in the studied years. $\mathrm{P}_{\mathrm{n}}$ was found to correlate positively and significantly with $\mathrm{g}_{\mathrm{s}}, \mathrm{E}$ and assimilation area of leaf, stem and spike and leaf area index under rainfed (Table 3). The RWC positively correlated with $\operatorname{Chl}(\mathrm{a}+\mathrm{b})$ and $\operatorname{Car}(\mathrm{x}+\mathrm{c})$ contents. The highest positive correlations were detected between $\mathrm{P}_{\mathrm{n}}$ and $\mathrm{g}_{\mathrm{s}}$, as well as between $\mathrm{Chl}(\mathrm{a}+\mathrm{b})$ and $\mathrm{Car}(\mathrm{x}+\mathrm{c})$ contents. Correlations between grain yield and physiological traits $\left(\mathrm{P}_{\mathrm{n}}, \mathrm{RWC}\right.$, LAA, SAA, SPAA) were negative under both irrigated and rainfed conditions. These correlations mean that grain yield is less associated with physiological parameters. 


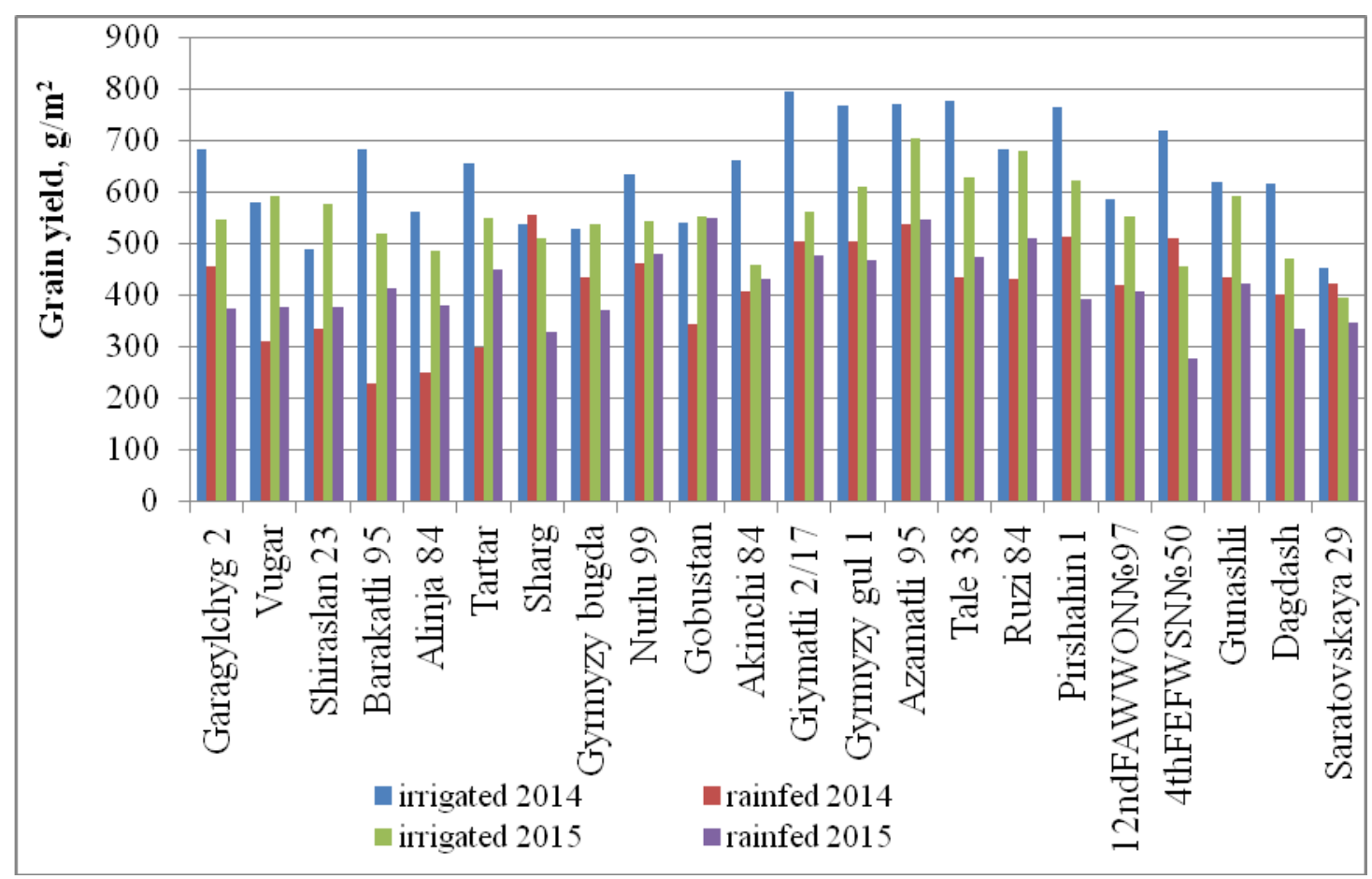

Figure 11. Effect of drought stress on grain yield. Each value represent mean of 3 replicates

Table 3. Correlations between grain yield and physiological traits (2014/15 growing season).

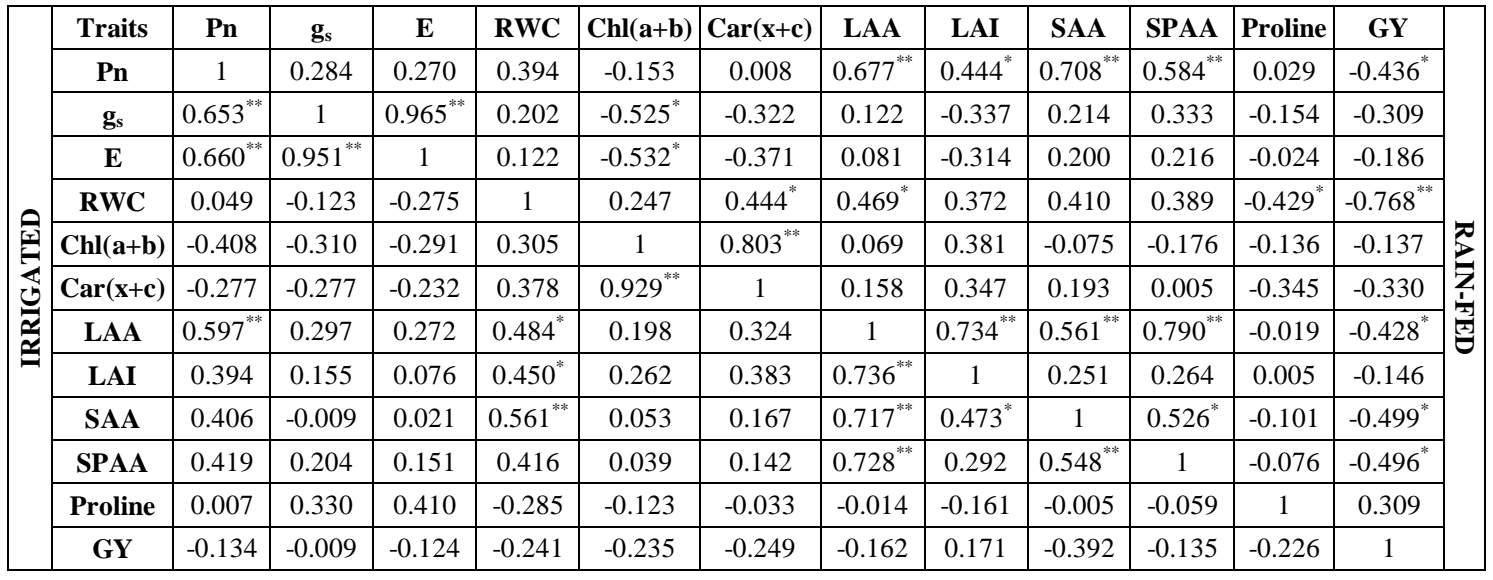

${ }^{* *}$ Correlation is significant at the 0.01 level; ${ }^{*}$ Correlation is significant at the 0.05 level. $\mathrm{P}_{\mathrm{n}}$ - photosynthesis rate, $\mathrm{g}_{\mathrm{s}}$-stomatal conductance, E-transpiration rate, RWC-relative water content, Chl- chlorophyl, Car-carotenoids, LAA-leaf assimilation area per stem, LAI-leaf area index, SAA-stem assimilation area, SPAA-spike assimilation area, GY-grain yield

\section{Discussion}

It was reported that water stress decreased $\mathrm{P}_{\mathrm{n}}, \mathrm{g}_{\mathrm{s}}$, E values of wheat genotypes at different growth stages (Hassan, 2006; Shan et al., 2012). In the present study, soil water deficit caused a decrease in $P_{n}, g_{s}$, and $E$ values. Limitation of $P_{n}$ is related to the decrease in $g_{s}$ and mesophyll conductance $\left(g_{m}\right)$ (Allahverdiyev et al., 2015). The $P_{n}$ had a positive and significant correlation with $g_{m}$, negative and significant correlation with $\mathrm{C}_{\mathrm{i}}$ under both irrigated and rainfed field conditions. $\mathrm{C}_{\mathrm{i}}$ had a positive, significant correlation with $g_{s}$, negative and significant correlation with $g_{m}$. Flexas et al. (2009) 
showed that $\mathrm{P}_{\mathrm{n}}$ and $\mathrm{C}_{\mathrm{i}}$ had a strong correlation with $\mathrm{g}_{\mathrm{s}}$ in both field-grown and potted grape wine plants. An increase in $\mathrm{C}_{\mathrm{i}}$ indicates predominance of limitation through mesophyll conductance. Under drought condition, the $\mathrm{C}_{\mathrm{i}} / \mathrm{C}_{\mathrm{a}}$ ratio $\left(\mathrm{C}_{\mathrm{a}}\right.$-ambient $\mathrm{CO}_{2}$ concentration) was also increased (unpublished dates). After watering of irrigated plots there was a competition between $\mathrm{CO}_{2}$ and water vapor in the passage through stomata in favor of transpiration. Our results showed that the wheat genotypes Shiraslan 23, Tartar, Sharg, Giymatli 2/17, Tale 38, $4{ }^{\text {th }}$ FEFWSNNo50, Dagdash revealed a higher $\mathrm{P}_{\mathrm{n}}$ both under irrigated and drought stress conditions. There are inconsistent reports about the relationship between gas exchange characteristics and growth or yield of different cultivars (Ashraf and Harris, 2013). Our results showed that high gas exchange characteristics $\left(P_{n}, g_{s}, E\right)$ of the genotypes Tartar, Sharg, Giymatli 2/17, Tale 38, $4{ }^{\text {th }}$ FEFWSN№50, Dagdash positively associated with assimilation area formation and dry mass accumulation. A positive association of gas exchange characteristics with grain yield was not strongly fixed. No significant correlation was found between leaf gas exchange parameters and grain yield (Bogale et al., 2011). The absence of correlation between photosynthetic parameters and grain yield is caused by biotic and abiotic factros whose limiting effect can be noticed during the phase of assimilate transport from the source (green photosynthetic organ) to the sink (spike, grain) (Sharkey et al., 1995).

Despite the fact that the gas exchange parameters were strongly influenced by drought, RWC remained relatively higher, especially in the taller genotypes Sharg, Gyrmyzy bugda, Dagdash, and Saratovskaya 29. A decrease in the RWC in response to drought stress was noted in wheat genotypes (Wu et al., 2014). In fact, although components of plant water relations are affected by reduced availability of water, stomatal opening and closing are more strongly affected (Anjum et al., 2011). In our opinion, a strong reduction of $\mathrm{g}_{\mathrm{s}}$ allows keeping the RWC at a high level. Under drought stress proline content increased about sevenfold in some genotypes. Proline is osmotically active and contributes to membrane stability, also acts as a signaling regulatory molecule able to activate multiple responses that are components of the adaptation process (Maggio et al., 2002). We revealed a positive correlation between proline content and grain yield under drought condition. Water deficit caused a decrease in Chl a, b and $\operatorname{Car}(\mathrm{x}+\mathrm{c})$ contents of wheat genotypes, that is in consistent with results of other authors (Chandrasekar et al., 2000). Saving large leaf area per stem under conditions of water scarcity is a good indicator, allowing greater accumulation of photoassimilates transported to the ear. In addition, relatively higher tillering capacity of bread wheat genotypes increased the leaf area index, contributed to greater accumulation of photoassimilates in a unit of assimilating area. Nonleaf organs (stem, spike, leaf sheath) are resistant to water deficit, and are important source of photosynthetic carbon assimilation under drought condition during the grain filling phase (Inoue et al., 2004) A large assimilation area of stem is linked with higher plant height or larger diameter of stem of the studied wheat genotypes. Grain yield is a result of many physiological processes (photosynthesis, respiration etc.), agronomical and yield traits that are under influence of environment. Our results showed that genotypes of bread wheat are more productive than that of durum wheat. Drought stress more affected on grain yield of durum wheat genotypes. Our results showed that grain yield of wheat genotypes is more related to yield components: spike number per unit area, biological yield, and harvest index under rainfed condition (Allahverdiyev, 2016). 
Acknowledgements. The authors are thankful to Science Development Foundation under the President of the Republic of Azerbaijan for the financial support of conducting this study (EIF-KEPTL-2-2015-1(25)-56/35/3).

\section{REFERENCES}

[1] Aghanejad, M., Mahfoozi, S., Shargi, Y. (2015): Effects of late-season drought stress on some physiological traits, yield and yield components of wheat genotypes. - Biological Forum-An International Journal 7: 1426-1431.

[2] Allahverdiyev, T. (2016): Yield and yield traits of durum wheat (Triticum durum Desf.) and bread wheat (Triticum aestivum L.) genotypes under drought stress. - Genetika 48: 717-727.

[3] Allahverdiyev, T. I., Talai, J. M., Huseynova, I. M., Aliyev, J. A. (2015): Effect of drought stress on some physiological parameters, yield and yield components of durum (Triticum durum Desf.) and bread (Triticum aestivum L.) wheat genotypes. - Ekin Journal of Crop Breeding and Genetics 1: 50-62.

[4] Alvaro, F., Isidro, J., Villegas, D., Garcia del Moral, L. F., Royo, C. (2008): Breeding Effects on Grain Filling, Biomass Partitioning, and Remobilization in Mediterranean Durum Wheat. - Agronomy Journal 100: 361-370.

[5] Anjum, S., Xie, X., Wang, L. C., Saleem, M. F., Man, Ch., Lei, W. (2011): Morphological, physiological and biochemical responses of plants to drought stress. African Journal of Agricultural Research 6: 2026-2032.

[6] Ashraf, M., Harris, P. J. C. (2013): Photosynthesis under stressful environments: An overview. - Photosynthetica 51: 163-190.

[7] Bates, L., Waldren, R., Teare, I. (1973): Rapid determination of free proline for waterstress studies. - Plant and Soil 39: 205-207.

[8] Bogale, A., Tesfaye, K., Geleto, T. (2011): Morphological and physiological attributes associated to drought tolerance of Ethiopian durum wheat genotypes under water deficit condition. - Journal of Biodiversity and Environmental Sciences 1: 22-36.

[9] Chandrasekar, V., Sairam, R. K., Srivastava, G. C. (2000): Physiological and biochemical responses of Hexaploid and Tetraploid wheat to drought tress. - Journal of Agronomy and Crop Science 185: 219-227.

[10] Changhai, S., Baodi, D., and Yunzhou, Q. (2010): Physiological regulation of high transpiration efficiency in winter wheat under drought conditions. - Plant, Soil \& Environment 56: 340-347.

[11] Condon, A. G., Richards, R. A., Rebetzke, G. J., Farquhar, G. D. (2004): Breeding for high water-use efficiency. - Journal Experimental Botany 55: 2447-2460.

[12] Flexas, J., Barón, M., Bota, J., Ducruet, J. M., Gallé, A., Galmés, J., Jiménez, M., Pou, A., Ribas-Carbó, M., Sajnani, C., Tomas, M., Medrano, H. (2009): Photosynthesis limitations during water stress acclimation and recovery in the drought-adapted Vitis hybrid Richter110 (V. berlandieri xV. rupestris). - Journal of Experimental Botany 60: 2361-2377.

[13] Flexas, J., Medrano, H. (2002): Drought-inhibition of photosynthesis in $\mathrm{C}_{3}$ plants: stomatal and non-stomatal limitations revisited. - Annals of Botany 89: 183-189.

[14] Hassan, A. I. (2006): Effect of water stress and high temperature on gas exchange and chlorophyll fluorescence in Triticum aestivum L. - Photosynthetica 44: 312-315.

[15] Inoue, I., Inanaga, S., Sugimoto, Y., An, P., Eneji, A. E.(2004): Effect of drought on ear and flag leaf photosynthesis of two wheat cultivars differing in drought resistance. Photosynthetica 42: 559-565.

[16] Kvët, J., Marshall, K. (1971): Assessment of Leaf Area and Other Assimilating Plant Surfaces. - In: Šesták, Z. et al. (eds.) Plant Photosynthetic Production. Manual of Methods. Dr. W. Junk N. V. Publ., The Hague. 
[17] Lawlor, D., Cornic, G. (2002): Photosynthetic carbon assimilation and associated metabolism in relation to water deficits in higher plants. - Plant, Cell \& Environment 25: 275-294.

[18] Lichtenthaler, H. (1987): Chlorophylls and carotenoids: Pigments of photosynthetic bio membranes. - Methods in Enzymology 148: 350-382.

[19] Maggio, A., Miyazaki, S., Veronese, P., Fujita, T., Ibeas, J. I., Damsz, B., Narasimhan, M. L., Hasegawa, P. M., Joly, R. J., Bressan, R. A. (2002): Does proline accumulation play an active role in stress induced growth reduction? - Plant Journal 31: 699-712.

[20] Monneveux, P., Jing, R., Misra, C. S. (2012): Phenotyping for drought adaptation in wheat using physiological traits. - Frontiers in Physiology 3: 429.

[21] Nachit, M., Elouafi, I. (2004): Durum Wheat Adaptation in the Mediterranean Dryland: Breeding, Stress Physiology, and Molecular Markers. - In: Nachit, M., Elouafi, I. (eds.) Challenges and Strategies for Dryland Agriculture (CSSA special publication no. 32). Crop Science Society of America and American Society of Agronomy, Madison, WI.

[22] Pingali, P. L. (1999): World Wheat Facts and Trends. Global Wheat Research in a Changing World: Challenges and Achievments. - CIMMYT, Mexico.

[23] Quarrie, S., Stojanovic, J., Pekic, S. (1999): Improving drought resistance in small grained cereals: A case study, progress and prospects. - Plant Growth Regulation 29: 1-21.

[24] Reynolds, M. P., Curtis, B. C., Rajaram, S., Macpherson, H. G. (2002): Physiological Approaches to Wheat Breeding: Bread Wheat. - FAO, Rome.

[25] Shan, C. J., Tang, Y. X., Yang, W. P., Zhao, X. L., Ren, X. J., Li, Y. Z. (2012): Comparison of photosynthetic characteristics of four wheat (Triticum aestivum L.) genotypes during jointing stage under drought stress. - African Journal of Agricultural Research 7: 1289-1295.

[26] Sharkey, T. D., Laporate, M. M., Micallef, B. J., Shewmaker, C. K., Oakes, J. W. (1995): Sucrose Synthesis, Temperature, and Plant Yield. - In: Maths, P. (ed.) From Light to Biosphere. Kluwer Academic Publishers, Dordrecht.

[27] Wright, G., Rachaputi, N. (2004): Drought and Drought Resistance. - In: Goodman, R. M. (ed.) Encyclopedia of Plant and Crop Science. Marcel Dekker, New York: 386-390.

[28] Wu, Y., Guo, Q., Tian, F., Wang, W. (2014): Differences in physiological characteristics between two wheat cultivars exposed to field water deficit conditions. - Russian Journal of Plant Physiology 61: 451-459. 